\title{
Effect of Compensation and Detuning of Single Tuned Shunt Passive Filter on Harmonics of Industrial Distribution System
}

\author{
Nilesh B. Mirajkar, R.M. Dharaskar, P. Kolhe* and M.H. Tharkar \\ Diploma in Fisheries Engineering, Ratnagiri, Dr. BSKKV, Dapoli, India \\ *Corresponding author
}

\section{A B S T R A C T}

\section{Keywords \\ Harmonics, Power system, Passive \\ filter, Industrial distribution system \\ Article Info \\ Accepted: \\ 18 January 2019 \\ Available Online: \\ 10 February 2019}

\section{Introduction}

With recent development of power electronics technology, nonlinear loads are created, in which the current is not proportional to the applied voltage. Voltages and currents in the power system differ from a single sinusoidal frequency, then distortion is said to be present in the system and they are the major sources of harmonic distortion in a power distribution system. These harmonics cause faulty operation and overheating of equipment's in the power system. Other problems consist transformer overloading and heating, meter errors and power cable faults. To overcome such faults and problems, harmonic mitigation technique is more important for both service providers and customers. Filtering of harmonics using passive filter is one of the simple and earliest methods used to address harmonic mitigation issues. These power quality issues are led to implementation of standards and guidelines such as IEEE-519 for controlling harmonics on the distribution power system along with the recommended limits. The 5\% voltage distortion limit was recommended below 69 $\mathrm{kV}$ while the limit on the current distortion is fixed in the range of $2.5 \%$ to $20 \%$ depending upon the size of the customer and the system voltage $(1,2,3,4)$. 
Many researches have been carried out on power harmonic mitigation using different types of filters. The problem of power harmonics in power distribution systems has been studied by using passive power filters (4-6). The MATLAB modeling and simulation of single tuned Passive filter has been studied. This type of filter has advantages in terms of low cost and can be used to improve system power factor because it compensates the reactive power to the power system. Passive filters are considered as one of the simple and most economical way for mitigating harmonics. This paper shows the effect of compensation and detuning of single tuned shunt passive filter on harmonics of industrial distribution system.

The main objective of this paper is to study the effect of compensation and detuning of single tuned shunt passive filter on harmonics of industrial distribution system

\section{Power system data}

The data is collected for the industry C'Cure Building Products. This three-phase system and single tuned power filter is designed and modeled in Matlab. A list of the system parameters and system harmonic data considered in the simulation is given in Table 1 and 2.

\section{Matlab Simulink model}

The Single tuned passive power filter consists of series combination of resistance, inductor and capacitor. Figure 1 shows the Matlab Simulink model of designed system. The main components of the above system are main supply, nonlinear load, single tuned passive filter.

Table.1 System parameters

\begin{tabular}{|l|l|l|l|l|l|l|l|}
\hline Parameter & p.f & $\begin{array}{l}\text { Frequency } \\
(\mathbf{H z})\end{array}$ & $\begin{array}{l}\text { Phase } \\
\text { angle } \\
(\mathbf{d e g r e e})\end{array}$ & $\begin{array}{l}\text { Real } \\
\mathbf{p o w e r} \\
\mathbf{( k W )}\end{array}$ & $\begin{array}{l}\text { Reactive } \\
\text { power } \\
\mathbf{( k V A r )}\end{array}$ & $\begin{array}{l}\text { Load } \\
\text { resistance } \\
(\mathbf{o h m})\end{array}$ & $\begin{array}{l}\text { Load } \\
\text { inductance } \\
(\mathbf{m H})\end{array}$ \\
\hline Phase1 & 0.738 & 50.09 & 42.4 & 18.4 & 16.8 & 2.0826 & 6.0533 \\
\hline Phase 2 & 0.694 & 50.09 & 46.1 & 19.2 & 19.9 & 1.7590 & 6.0533 \\
\hline Phase 3 & 0.751 & 50.09 & 41.4 & 21.0 & 18.4 & 1.8202 & 5.1081 \\
\hline
\end{tabular}

Table.2 System Harmonic Data

\begin{tabular}{|c|c|c|}
\hline \multicolumn{2}{|c|}{ Order of the Harmonics } & THD(\%) \\
\hline Phase1 & Inst. Current(A) & 27.4 \\
\cline { 2 - 3 } & Inst. Voltage(V) & 2.8 \\
\hline \multirow{2}{*}{ Phase2 } & Inst. Current(A) & 27.8 \\
\cline { 2 - 3 } & Inst. Voltage(V) & 3.4 \\
\hline \multirow{2}{*}{ Phase3 } & Inst. Current(A) & 26.8 \\
\cline { 2 - 3 } & Inst. Voltage(V) & 3.1 \\
\hline
\end{tabular}


Table.3 Filter Parameters

\begin{tabular}{|c|c|c|c|c|c|c|}
\hline Parameters & \multicolumn{2}{|c|}{ Phase 1 } & \multicolumn{2}{c|}{ Phase 2 } & \multicolumn{2}{c|}{ Phase 3 } \\
\hline & $5^{\text {th }}$ & $7^{\text {th }}$ & $5^{\text {th }}$ & $7^{\text {th }}$ & $5^{\text {th }}$ & $7^{\text {th }}$ \\
\hline $\mathbf{Q c}(\mathbf{k V A r})$ & 8 & 8 & 10 & 10 & 9 & 9 \\
\hline $\mathbf{X c}(\mathbf{o h m})$ & 8.3786 & 8.3786 & 6.6822 & 6.6822 & 7.2136 & 7.2136 \\
\hline $\mathbf{C}(\mathbf{u F})$ & 379.91 & 379.91 & 476.35 & 476.35 & 441.25 & 441.25 \\
\hline $\mathbf{X I}(\mathbf{o h m})$ & 0.3351 & 0.1709 & 0.2672 & 0.1363 & 0.2885 & 0.1472 \\
\hline $\mathbf{L}(\mathbf{m H})$ & 1.0668 & 0.5443 & 0.85 & 0.434 & 0.918 & 0.4686 \\
\hline $\mathbf{R}(\mathbf{o h m})$ & 0.04117 & 0.0294 & 0.0328 & 0.0234 & 0.0354 & 0.0253 \\
\hline $\mathbf{Q}$ & 40.7 & 40.7 & 40.7 & 40.7 & 40.7 & 40.7 \\
\hline
\end{tabular}

Table.4 Current THD, Voltage THD and p.f before and after filter is turned on

\begin{tabular}{|l|l|l|l|l|l|l|l|l|l|}
\hline parameter & \multicolumn{3}{|l|}{ Current THD(\%) } & \multicolumn{2}{l|}{ Voltage THD(\%) } & \multicolumn{3}{l|}{ Power factor } \\
\hline $\begin{array}{l}\text { Before filter } \\
\text { turned on }\end{array}$ & 27.4 & 27.8 & 26.8 & 2.8 & 3.4 & 3.1 & 0.738 & 0.694 & 0.751 \\
\hline $\begin{array}{l}\text { After filter } \\
\text { turned on }\end{array}$ & 0.87 & 0.63 & 2.85 & 0.44 & 0.36 & 0.95 & 0.99 & 0.99 & 0.99 \\
\hline
\end{tabular}

Table.5 Effect of compensation on THD

\begin{tabular}{|c|c|c|}
\hline Compensation & $\begin{array}{c}\text { Current THD } \\
(\boldsymbol{\%})\end{array}$ & $\begin{array}{c}\text { Voltage THD } \\
(\boldsymbol{\%})\end{array}$ \\
\hline $\mathbf{8 0 \%}$ & $\mathbf{1 . 0 9}$ & $\mathbf{0 . 5 6}$ \\
\hline $\mathbf{9 0 \%}$ & $\mathbf{0 . 9 8}$ & $\mathbf{0 . 5 0}$ \\
\hline $100 \%$ & $\mathbf{0 . 8 7}$ & $\mathbf{0 . 4 4}$ \\
\hline $110 \%$ & $\mathbf{0 . 7 8}$ & $\mathbf{0 . 4 0}$ \\
\hline $120 \%$ & $\mathbf{0 . 7 0}$ & $\mathbf{0 . 3 7}$ \\
\hline
\end{tabular}

Table.6 Effect of detuning on THD

\begin{tabular}{|c|c|c|}
\hline Detuning & Current THD(\%) & Voltage THD(\%) \\
\hline $\mathbf{3 \%}$ & 2.38 & 1.09 \\
\hline $\mathbf{5 \%}$ & 4.05 & 1.81 \\
\hline $\mathbf{7 \%}$ & 6.14 & 2.70 \\
\hline
\end{tabular}


Fig.1 Matlab Simulink model of designed system

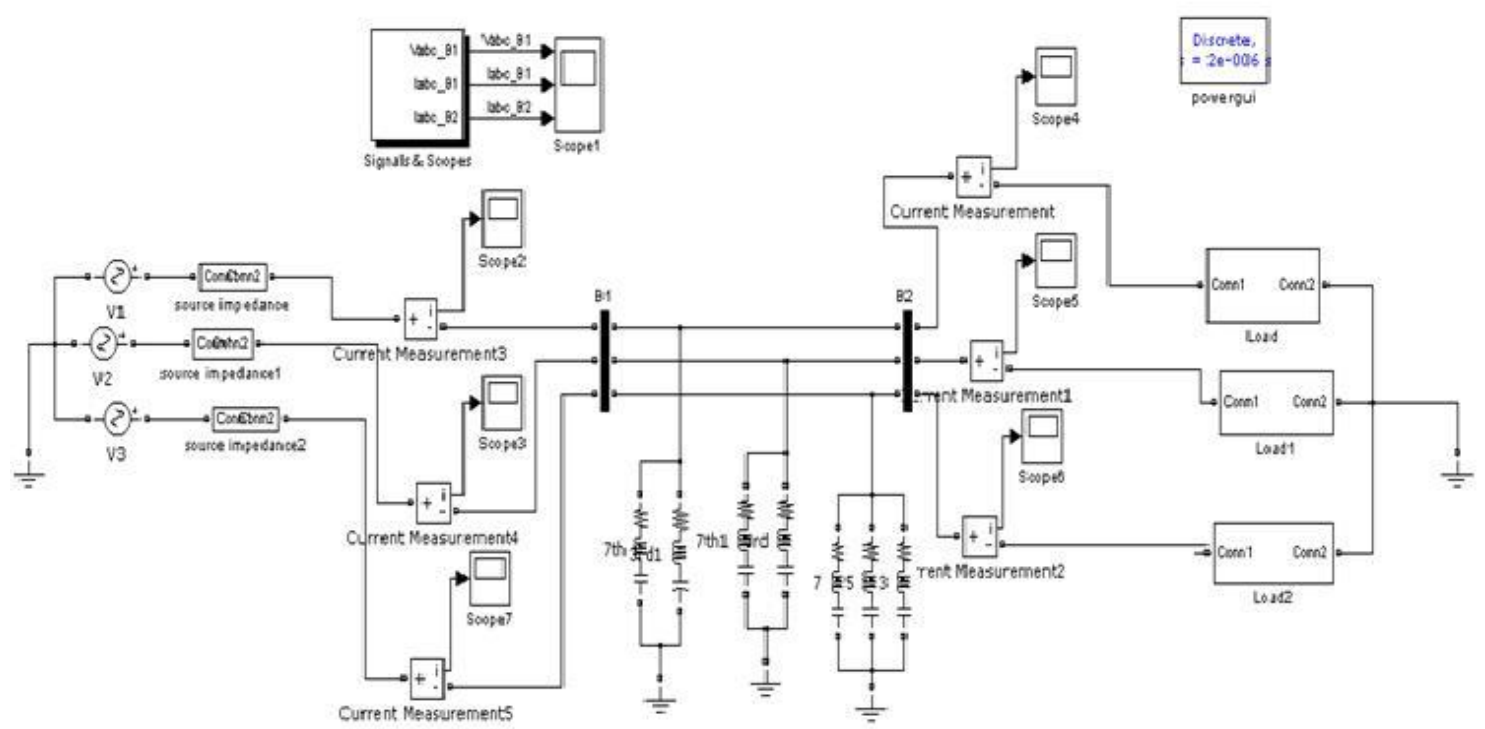

\section{Designed single tuned passive filter data}

The designed single tuned passive filters parameters are shown in following table 3 . After simulation, the current THD, voltage THD and power factor are shown in following table 4.

\section{Effect of compensation on THD}

If the compensation of single tuned shunt passive filter is increased and decreased, the results are comes out.

From the table 5 it is clear that, if the compensation is increased, the current THD and Voltage THD getting decreased and if compensation is decreased, the current THD and Voltage THD getting increased.

\section{Effect of dtuning on THD}

If the detuning of single tuned shunt passive filter is increased, the following results are comes out. From the table 6 it is clear that, if the detuning is increased, the current THD and Voltage THD getting increased (7-11).
From the Result, it is concluded that, if the compensation is increased, the current THD and Voltage THD getting decreased and if compensation is decreased, the current THD and Voltage THD getting increased. If the detuning is increased, the current THD and Voltage THD getting increased.

\section{References}

1. Active power filters: A review' by M.El-Habrouk, M.K. Darwish and P. Mehta.

2. Akagi, H., "Performance and modeling of a shunt active filter for installation on power distribution systems," to be presented at the 1996 IEEEPES International Conference on Harmonics and Quality of Power, Oct. 16-18, 1996.

3. Arrilaga, J., Bradley, D.A. and Bodger, P.S.: 'Power system harmonics'

4. El-Saadany, F, "Parameters Affecting Harmonic Propagation and Distribution Levels in Non-Linear Distribution systems," transmission 
and Distribution Conference and Exposition, 2002.

5. Georg J. Wakileh' Power System Harmonics'

6. Gonzalez, D.A. and McCall, J.C., "Design of filicrs to reduce harmonic distortion in industrial power system." IEEE Trun. On Induswiol Applicorion, Vol. 3 I, May - Jan, 1987.

7. IEEE Guide for Application and Specification of Harmonic Filters. IEEE Std 1531.-2003

8. IEEE Recommended Practices and Requirements for Harmonic Control in Electrical Power Systems. IEEE Std 519-1992.
9. Peng, F.Z., M. Kohata, and H. Akagi, "Compensation characteristics of shunt and series active filters," in Proc. 1992 Chinese-Japanese Power Electronics Cont. Beijing, China, 1992, pp. 381-387.

10. Sasaki, H. and T. Machida, "A new method to eliminate ac harmonic currents by magnetic compensationConsideration on basic design," IEEE Trans. Power Appl. Syst., vol. PAS90, pp. 2009-2019, 1971.

11. Sutanto, D., M. Boou-rabee, K.S. Tam, C.S. Chang. Passive and active Harmonic filters for industrial power system.

\section{How to cite this article:}

Nilesh B. Mirajkar, R M. Dharaskar, P. Kolhe and Tharkar, M.H. 2019. Effect of Compensation and Detuning of Single Tuned Shunt Passive Filter on Harmonics of Industrial Distribution System. Int.J.Curr.Microbiol.App.Sci. 8(02): 2527-2531. doi: https://doi.org/10.20546/ijcmas.2019.802.294 